\title{
ENTREPRENEURIAL INTENTION OF PRODUCTION ENGINEERING STUDENTS IN AMAZONAS/BRAZIL
}

\author{
Júnior Garcia Araújo \\ Hard Sciences and Technology Institute (ICET/UFAM), Brazil \\ E-mail: jrgarciagv@outlook.com
}

Moisés Israel Belchior de Andrade Coelho Hard Sciences and Technology Institute (ICET/UFAM), Brazil E-mail: moises.acoelho@gmail.com

Submission: $14 / 02 / 2018$

Revision: 11/04/2018 Accept: 23/04/2018

\section{ABSTRACT}

This work aims to investigate an entrepreneurial intention of production engineering students in Hard Sciences and Technology Institute (ICET) linked to Federal University of Amazonas (UFAM). Regarding the methodology, this research is quantitative, regarding the approach of the problem, exploratory, regarding the objectives of the research, and a case study with regard to the technical procedure adopted. The research sample was formed by courses of production engineering course and contains a participation of 100 students. The research techniques used were: indirect documentation and extensive direct observation through the application of the forms of entrepreneurial intention with the students. In terms of results, the following stand out more than half of the students are not entrepreneurial products; however, almost all of their users are in a position to become entrepreneurs; strong indication for selfemployment; search for an innovative idea as the main barrier to entrepreneurship. The study points to a proactive stance with regard to entrepreneurship even considering that as areas of engineering, they concentrate a large part of their professionals as employees in public or private companies. 
INDEPENDENT JOURNAL OF MANAGEMENT \& PRODUCTION (IJM\&P)

http://www.ijmp.jor.br

v. 9, n. 4, October - December 2018

ISSN: 2236-269X

DOI: 10.14807/ijmp.v9i4.786

The relevance of the research lies in evidencing the growth of entrepreneurship among the discourses of production engineering so that the university contributes to the formation of professionals who create projects with high added value, promoting technological development and innovation and impacting local development.

Keywords: Entrepreneurship; Entrepreneurial Intention; Students; Production Engineering; Amazonas

\section{INTRODUCTION}

For Schwab (2015), we are on the verge of a technological revolution that will fundamentally change the way we live, work and relate. The first industrial revolution used water and steam to mechanize production; the second used electricity to create mass production; the third used electronics and information technology to automate production; Finally, the fourth revolution is building upon the third digital revolution that has been taking place since the middle of the last century.

The era of capitalism is passing, not rapidly but inevitably (RIFKIN, 2014); for the author, the new economic paradigm (collaborative communities) is growing from the emergence of a hybrid economy, part of the capitalist market and part of collaborative communities. The two economic systems often work in parallel and sometimes compete, finding synergies where they can add value to each other, benefiting each other.

From Schumpeter's (1997) point of view, there is a relationship between innovation, the creation of new markets and entrepreneur action; for the author, the entrepreneur begins to change the behavior of consumers by creating the desire for new things or that differ from what these consumers would commonly buy. In this context, the creative destruction would be the replacement of old products and habits of consuming by new ones.

For Schumpeter (1961) innovation is related to new consumer goods, new methods of production or transportation, new markets and new forms of organization; innovation is the impulse that keeps the machine of capitalism running. With respect to creative destruction, Schumpeter mentions that it is the process that constitutes capitalism and based on it every company must adapt to survive. The impact of innovations reduces the effect on the structure of a long-term industry and 
INDEPENDENT JOURNAL OF MANAGEMENT \& PRODUCTION (IJM\&P)

http://www.ijmp.jor.br

v. 9, n. 4, October - December 2018

ISSN: 2236-269X

DOI: 10.14807/ijmp.v9i4.786

reduces the importance of practices aimed at retaining traditional positions and profits based on those positions.

According to Ács et al. (2017), the entrepreneur is a person with the vision to observe an innovation and the ability to bring to market. Entrepreneurship is about creating jobs and growth through innovation. Entrepreneurs are the bridge between invention and commercialization, being able to be in sectors of high or low technology, as well as of any technology; without them, the innovations are in Research \& Development (R \& D) laboratories and in universities.

In short, this work aims to investigate the entrepreneurial intention of production engineering students in Hard Sciences and Technology Institute (ICET) linked to Federal University of Amazonas (UFAM). The work is structured in four parts: (1) literature review; (2) methodology; (3) results; (4) discussion, conclusion, and references.

\section{LITERATURE REVIEW}

\subsection{Entrepreneurship}

The history of entrepreneurship is similar to the history of man himself, taking into account that entrepreneurial behavior has always existed and that it was this behavior that motivated us to create, build and evolve (ALVES, 2011). Entrepreneurship is one of the main factors of economic development in a country, so in countries with an entrepreneurial culture, the prospects for economic growth are much higher (MALHEIROS et al., 2005).

One of the observed aspects is that entrepreneurship ceased to be a term exclusively related to business and to the companies, is seen as a behavior (VALE et al., 2008). Thus, entrepreneurship is defined as a behavior rather than a personality trait, so to act as entrepreneurs it is necessary to use tools based on the interest of seeking change, reacting to them and exploiting them as a business opportunity (MALHEIROS et al., 2005), that is, it is a form of thinking that emphasizes opportunities for threats (KRUEGER JR et al., 2000)

Entrepreneurship has varied characteristics that can manifest in different ways, which makes its concept difficult, and it is possible to point out that its origin is in the recognition of an opportunity or the need felt by the market. Entrepreneurship means doing something new, different, changing the current situation and constantly 
INDEPENDENT JOURNAL OF MANAGEMENT \& PRODUCTION (IJM\&P)

http://www.ijmp.jor.br

v. 9, n. 4, October - December 2018

ISSN: 2236-269X

DOI: 10.14807/ijmp.v9i4.786

seeking new business opportunities, focusing on innovation and the creation of value, entrepreneurship encompasses every form of innovation that has to do with the prosperity of the company (VIEIRA; RODRIGUES, 2014; DORNELAS, 2004).

More recently, Ács et al. (2014) introduced the concept of national entrepreneurship systems (SNES), characterized by resource allocation systems that are driven by the search for opportunities at the individual level through the creation of new ventures with their activities and its results regulated by specific institutional characteristics of the country.

Entrepreneurial ecosystems are composed of subsystems (pillars) that are aggregated to systems that can be optimized for performance at the ecosystem level. They are based on three important assumptions: (1) entrepreneurship is an action carried out and directed by agents based on incentives; (2) individual action is affected by a framework of institutional conditions; and (3) entrepreneurial ecosystems are complex, with multifaceted structures in which the elements interact for the performance of the productive system and require methods that allow the constituent elements to interact (ÁCS et al., 2017).

Thus, entrepreneurial ecosystems can be defined as a dynamic, institutionally integrated interaction between attitudes, skills and entrepreneurial aspirations, by individuals, that drive the allocation of resources through the creation and operation of new ventures.

\subsection{Entrepreneur}

The entrepreneur is one who, regardless of the branch of activity, creates a new company or acquires an existing one and introduces innovations, assuming the risks that exist with the enterprise. Regardless of the branch of activity, it creates a new company or acquires an existing one and introduces innovations, assuming the risks that exist with the enterprise (SAES; PITA, 2007).

Baumol et al. (2009), define individuals as entrepreneurs if in their economic activity they demonstrate initiative, imagination, and willingness to demand efforts in the pursuit of prosperity, power, and prestige. They divide entrepreneurs into two groups: innovators and imitators, where the former engage their companies in the quest to offer new products, new production processes or entry into new markets. 
INDEPENDENT JOURNAL OF MANAGEMENT \& PRODUCTION (IJM\&P)

http://www.ijmp.jor.br

v. 9, n. 4, October - December 2018

ISSN: 2236-269X

DOI: 10.14807/ijmp.v9i4.786

For Drucker (1986), entrepreneurs need to learn to practice systematic innovation, successful entrepreneurs try to create new and different values and new and different sensations rather than searching for sensational innovations. They convert a "material" into a "resource" or combine existing resources into a new, more productive configuration.

Vivarelli (2013) provides an investigation of the concept of entrepreneurship; the author presents the concept of the founder (founder), as being an adequate definition for the great majority of the actors that end up being denominated of entrepreneurs. The founders are actually what Schumpeter called clusters of followers. They are strongly influenced by their own history, in particular, their previous work experiences, family history, personal non-economic factors, among others. The founders do not conduct a technological renovation and economic growth, possessing a high level of bankruptcy.

The article by Baumol et al. (2009) analyzed innovative inventors and entrepreneurs called "superstars" considering a sample of 513 entrepreneurs and inventors in more than 30 countries. The authors evidenced that over the years there has been a growth of inventors and entrepreneurs with high levels of education, including masters and doctorates. In the case of the United States, both inventors and entrepreneurs have a better schooling than the majority of the population and compared them to each other, the inventors have a higher education level than the entrepreneurs.

Finally, they point out that the success of entrepreneurship requires a wide variety of general skills and that technology has grown cumulatively and in an increasingly complex way requiring more extensive educational preparation.

In the publication, Hermans et al. (2015) carry out a survey of the literature related to the entrepreneurial ambition and related concepts in this new research concept that has been emerging in recent years. The approach adopted by the authors offers an opportunity to develop a deep understanding of the motivations, ambitions, aspirations, intentions, and achievements in interactions with external opportunities and resources. The work of Lee et al. (2011), point out the relationship between a set of organizational and individual factors that contribute to entrepreneurial intent in IT professionals. 
INDEPENDENT JOURNAL OF MANAGEMENT \& PRODUCTION (IJM\&P)

http://www.ijmp.jor.br

v. 9, n. 4, October - December 2018

ISSN: 2236-269X

DOI: 10.14807/ijmp.v9i4.786

Cassar (2007) examines the possible impacts of career ratios on aspirations and expectations of growth and on actual growth. The study points to the importance that entrepreneurs place on financial success as a key factor in explaining the crosscutting differences in entrepreneur growth, the size desired for the entrepreneurship and the growth achieved.

Teixeira et al. (2011) carried out a study as the objective of analyzing the reasons that led a thirteen-year-old to start her own business, the life history was used as a data collection technique through an interview. The influence of the family in this walk was mainly analyzed and the characteristics that led to the success as an entrepreneur were identified; the research also realized that parental support was crucial to the creation and development of the business. Some entrepreneurial particularities found in other studies were easily identified in the young, such as determination, creativity, desire for independence, continuous learning and use of networks of relationships.

Silva et al. (2013) present a record of South Korea's historical economy in relation to the current factors related to innovation and entrepreneurial activity, offering a contributory analysis to the understanding of the country as an economic power that has stood out worldwide for the competitiveness of its organizations among other factors.

\subsection{Entrepreneurship intention}

In 2004, Inácio Júnior and Gimenez (2004) provided the translation, validation, and application of the Carland Entrepreneurship Index (CEI) as a tool to measure entrepreneurial potential. The sample consisted of 671 respondents among undergraduate and graduate students in business administration and ownermanagers of resident companies. The authors used the Back translation method and the use of statistical-descriptive techniques, hypothesis tests, factor analysis and reliability.

Lopes Júnior and Sousa (2005) provided the construction and validation of an entrepreneurial attitude measurement instrument applying to owner-managers of small retail companies. The sample consisted of 290 interviewees and the structured questionnaire was composed of 36 affirmative items using a Likert scale. The 
INDEPENDENT JOURNAL OF MANAGEMENT \& PRODUCTION (IJM\&P)

http://www.ijmp.jor.br

v. 9, n. 4, October - December 2018

ISSN: 2236-269X

DOI: 10.14807/ijmp.v9i4.786

questionnaire was called the Entrepreneurial Attitude Measurement Instrument (IMAE).

Santos (2008) provided a scale to help identify entrepreneurial potential in students, to train entrepreneurs or to select candidates for entry into incubators. The constructed scale was based on psychometric and statistical techniques (Cronbach's alpha and factorial analysis) and was composed of 57 items, four of which were to identify the entrepreneurial intention and the other 53 items to compose the scale of entrepreneurial potential. The sample consisted of 100 entrepreneurs.

Alves and Bornia (2011) developed a scale to measure entrepreneurial potential using Item Response Theory (TRI). The research sample consisted of 764 people who answered to an instrument composed of 103 items and the logistic model of two parameters of the TRI was used. The results showed that the scale is best suited to evaluate individuals with low to moderately high entrepreneurial potential, thus, the Item Response Theory allows new items to be calibrated in order to measure entrepreneurs with high entrepreneurial potential.

Finally, Vieira and Rodriguez (2014) we presented the preliminary results of the ENGEmpreende research developed to analyze the perceived attitudes and values associated with entrepreneurship by engineering students. The sample consisted of 387 engineering students from the University of Minho in Portugal.

\section{METHODOLOGY}

Regarding the approach to the problem, this research is characterized as quantitative because it considers that everything can be quantifiable, that is, translate into numbers opinions and information to classify and analyze them. In this case, the enterprising intentions of the students of the course of production engineering. As for the objectives, the research is exploratory by providing greater familiarity with the problem in order to make it explicit or to construct hypotheses, thus exploring the entrepreneurial characteristics of the students (SILVA; MENEZES, 2005).

According to Gil (2002), the case study is characterized by a detailed and exhaustive study of a few or even a single object, providing in-depth knowledge.

The approach used in the study to evaluate students' entrepreneurial intent was presented in Vieira and Rodrigues (2014). The questionnaire was composed of 
INDEPENDENT JOURNAL OF MANAGEMENT \& PRODUCTION (IJM\&P)

http://www.ijmp.jor.br

v. 9, n. 4, October - December 2018

ISSN: 2236-269X

DOI: 10.14807/ijmp.v9i4.786

12 (twelve) questions divided into two parts. The first part was called the "Profile of the respondents" and was composed of four questions related to the age group, gender, the student's period of study and monthly family income.

The second part was denominated "Entrepreneurial Intentions" and was composed of eight questions, with three questions to indicate " $x$ " and five questions filled according to the degree of agreement. For these questions a Likert scale was used, consisting of five levels of agreement: 1 - totally disagree, 2 - partially disagree, 3 - neutral, 4 - partially agree and 5 - totally agree.

The sampling of this research was intentional non-probabilistic (MARCONI; LAKATOS, 1990). The sample was formed by students of the production engineering course of the Institute of Exact Sciences and Technology (ICET/UFAM). ICET is linked to the Federal University of Amazonas (UFAM) and is located in the municipality of Itacoatiara, 265 km from Manaus/AM.

In all, 100 questionnaires were answered from 134 students enrolled in the production engineering course. In this way, the research indicates a level of confidence of $95 \%$.

In order to collect data, the following research techniques were used, according to Marconi and Lakatos (1990): (1) indirect documentation through bibliographic research (included bibliography related to the subject of study); and (2) extensive direct observation, through the application of forms of entrepreneurial intention.

The research was carried out in three moments: (1) the students' awareness about the objectives of the study occurred; (2) was the application of the forms of entrepreneurial intention; and concluding, (3) the data were tabulated and analyzed. For the analysis and interpretation of the data, position measurements were used and the data presentation was done through graphs.

\section{RESULTS}

\subsection{Profile of respondents}

The sample has a total of 100 respondents, being 28 students of the second period, 20 of the fourth period, 17 of the sixth, 13 of the eighth and 22 of the 10th period of the course. The classification by gender shows that the majority are women 
INDEPENDENT JOURNAL OF MANAGEMENT \& PRODUCTION (IJM\&P)

http://www.ijmp.jor.br

v. 9, n. 4, October - December 2018

ISSN: 2236-269X

DOI: 10.14807/ijmp.v9i4.786

among the interviewees, being 53 of the feminine gender and 47 of the masculine gender. Concerning the age range of the interviewees, 92\% of the students are 25 years old, $7 \%$ are between 26 and 35 years old, and only 1\% are between 35 and 45. Figure 1 shows the distribution by the monthly family income of the participants, $58 \%$ of the students have a monthly family income of no more than $R \$ 2,000.00$.

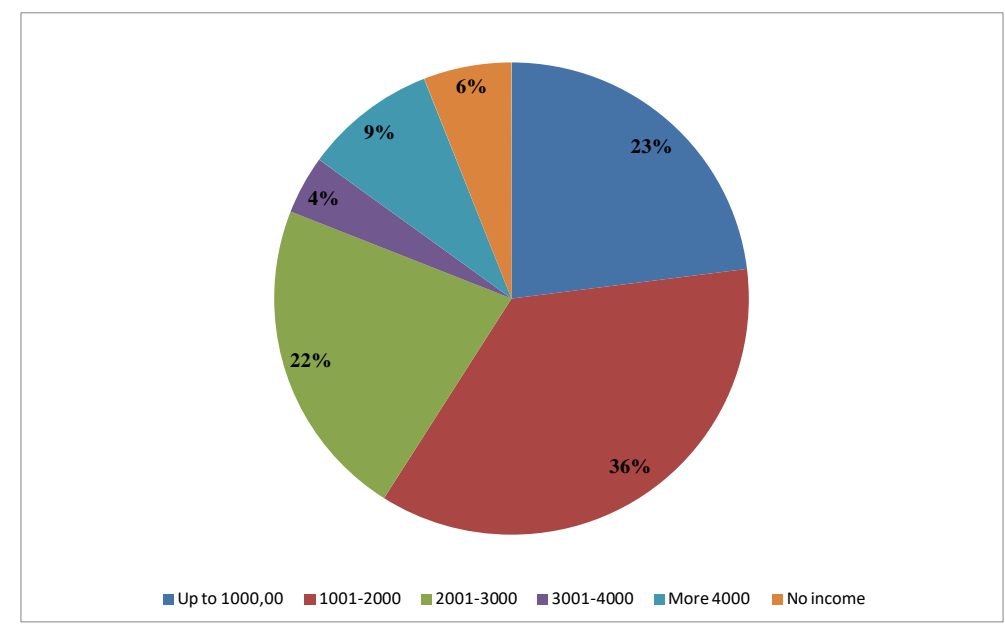

Figure 1: Income of respondents.

\subsection{Entrepreneurial intention}

The study starts asking about the entrepreneurial behavior of parents with the following question: "Has he grown up in an entrepreneurial family, does he have a father or a mother who owns a business?" As for the entrepreneurial behavior of the parents, $51 \%$ of the respondents admitted that the parents were never entrepreneurs, while $23 \%$ said that parents have their own active business, $13 \%$ that the business ended more than five years ago, $9 \%$ that the business ended up to five years and $4 \%$ did not know how to respond (Figure 2).

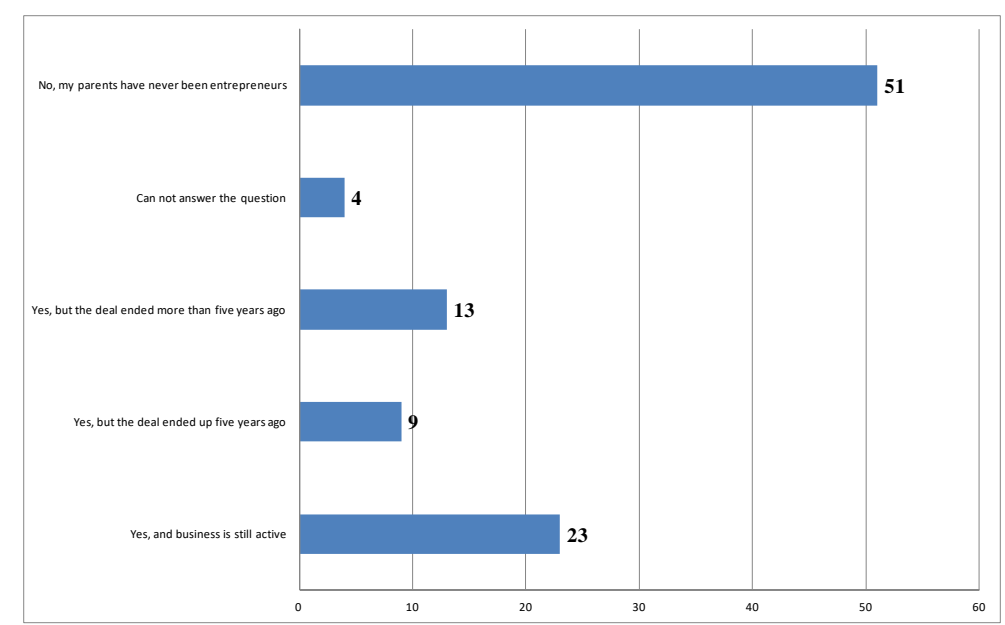

Figure 2: Entrepreneurial Behavior of Parents 
INDEPENDENT JOURNAL OF MANAGEMENT \& PRODUCTION (IJM\&P)

http://www.ijmp.jor.br

v. 9, n. 4, October - December 2018

ISSN: 2236-269X

DOI: $10.14807 /$ ijmp.v9i4.786

With regard to entrepreneurial intention (Figure 3), the following question was elaborated: "Have you ever seriously considered starting your own business?" The options presented posted a positive result with 44\% who stated they are determined to be their own boss in the future, $9 \%$ are already starting the process, $9 \%$ who are already their own boss. However, among the positive responses, $16 \%$ say they have abandoned the idea. In the case of negative responses, $25 \%$ reported never having thought about it.

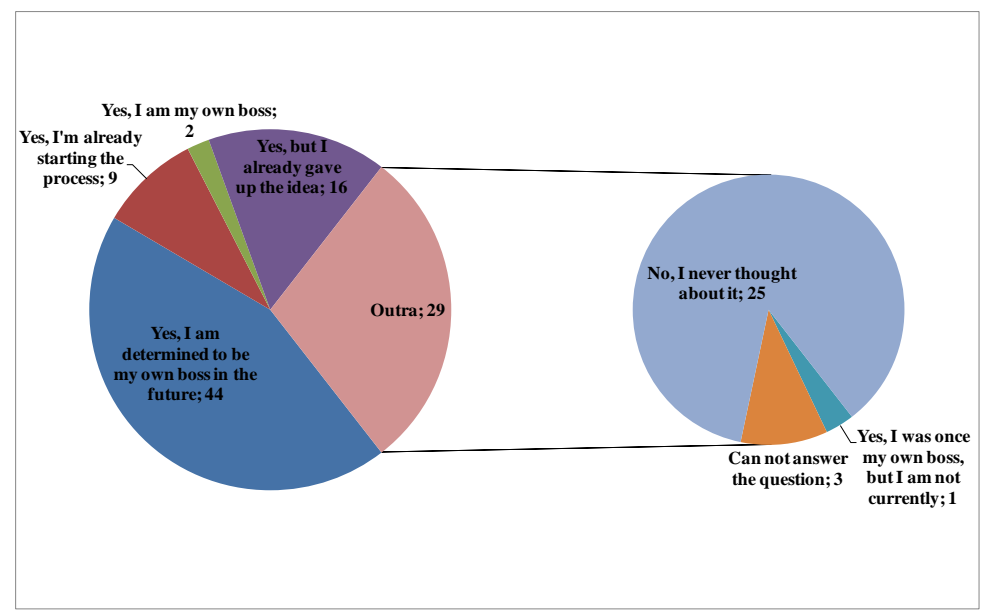

Figure 3: Entrepreneurial Intent

With regard to predisposition and attitudes about entrepreneurship, the following question was used: "If I had 30,000.00 reais, how would I invest this money?" The data show that 40 respondents assume that "I would invest in a business of my own". Identify the little interest in choosing the options: those who would deposit in a savings (24), invest in an investment fund (8), invest in a car or house (13) or others (15). Most would invest money in other options and not in the business itself (Figure 4).

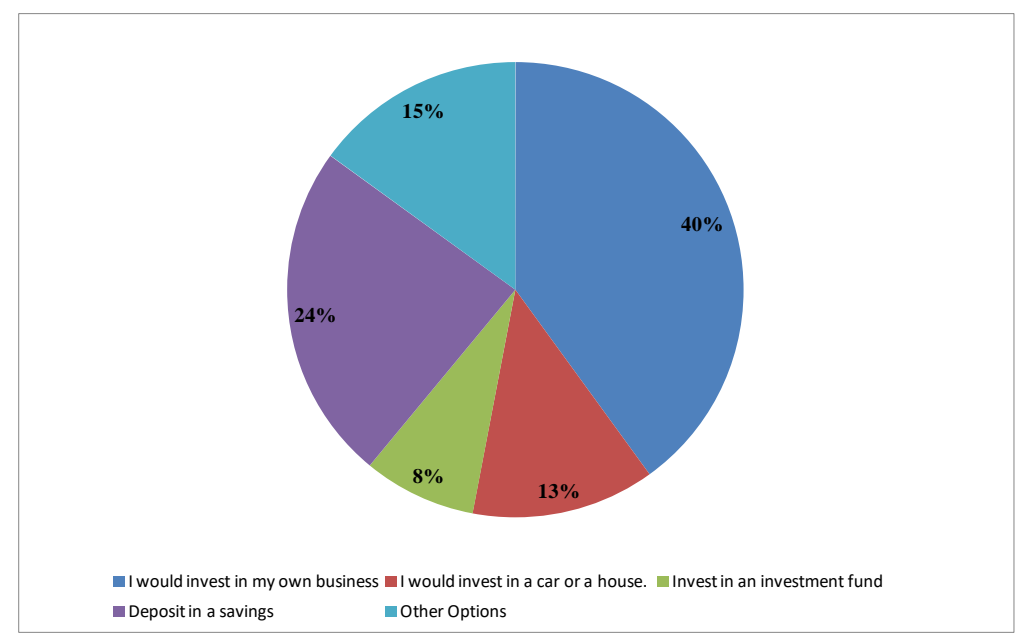

Figure 4: Predisposition and attitudes about entrepreneurship 
INDEPENDENT JOURNAL OF MANAGEMENT \& PRODUCTION (IJM\&P)

http://www.ijmp.jor.br

v. 9, n. 4, October - December 2018

ISSN: 2236-269X

DOI: 10.14807/ijmp.v9i4.786

Regarding the attitude toward self-employment, three items were evaluated: (1) I prefer to be my own employer to have a secure job; (2) I prefer to build a company of its own to be the manager of an existing one; and (3) I can only make good money if it is my own boss. For $51 \%$ of respondents admitted in a positive way that they prefer to be bosses instead of a secure job; those who say they prefer to build their own company to be the manager of an existing one correspond to $41 \%$; and $22 \%$ agree that it is only possible to make good money if they are their own boss (Figure 5).

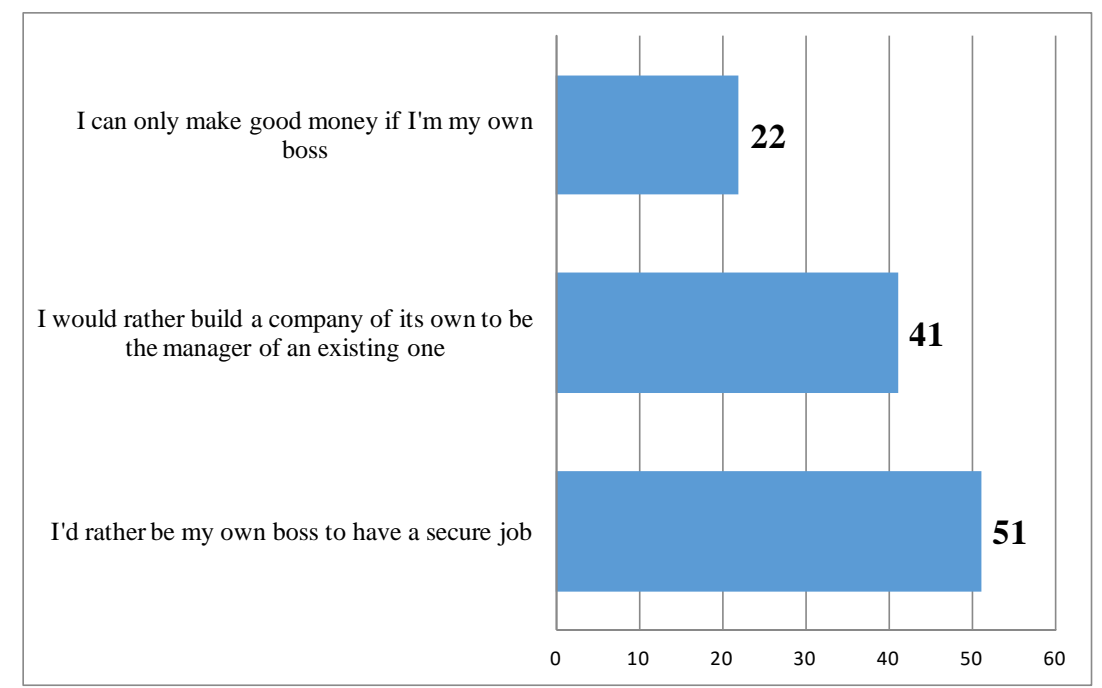

Figure 5: Attitude to self-employment (\% of positive responses)

In the case of the perceived image of the entrepreneur, seven questions are considered: (1) entrepreneurs have a positive image in society; (2) in business it is preferable to be an entrepreneur than an employee; (3) the success of an entrepreneur is strongly determined by "luck"; (4) training is more important than personality as a factor of success in entrepreneurship; (5) entrepreneurship impairs family life; (6) entrepreneurs are convinced; (7) entrepreneurship is basically an outlet or resource for people who have failed.

Figure 6 presents the positive results to the questions related to the perceived image of the entrepreneur. The responses indicate the positive image of the entrepreneurs, emphasizing the importance of having their own company, of seeing entrepreneurship as an alternative to traditional career thinking and the relevance of the entrepreneurial personality. 


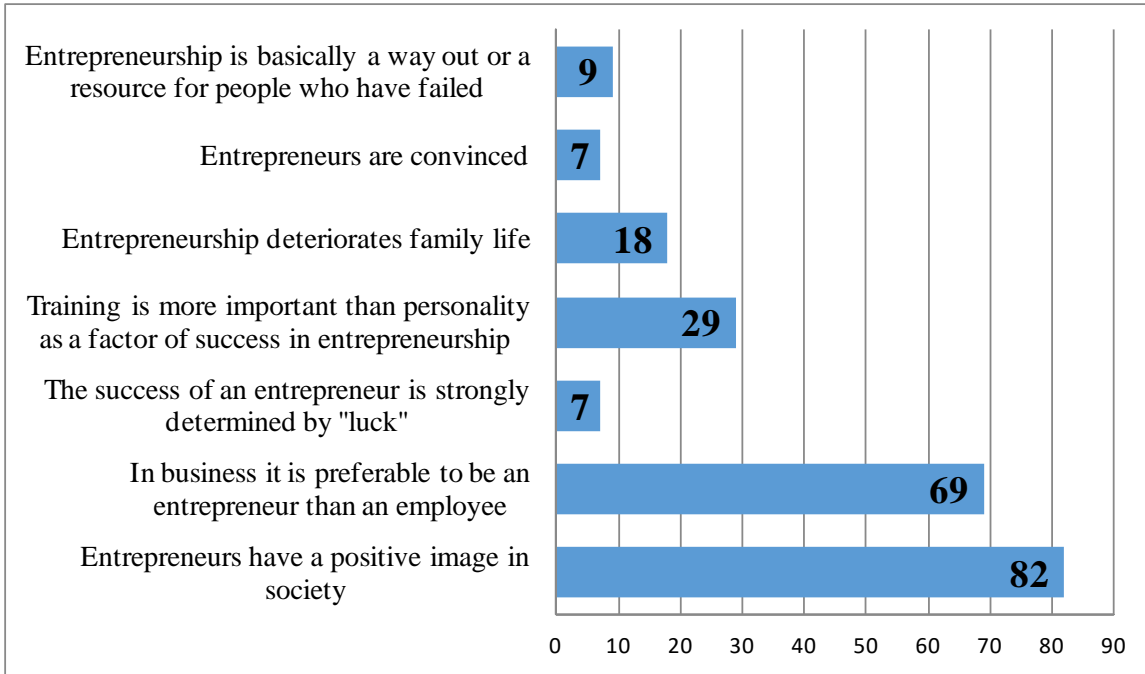

Figure 6: The perceived image of the entrepreneur (\% of positive responses)

With regard to the study on barriers to entrepreneurship, four questions were considered: (1) it is difficult to find an idea for a business that has not been identified; (2) banks do not easily give credit to start-ups; (3) Legislation is adverse to the management of a company; and (4) other factors.

Figure 7 indicates that $53 \%$ of students find it difficult to find a new idea; $45 \%$ in relation to the difficulties that the entrepreneurs have in obtaining lines of credit with the banks; and only $22 \%$ acknowledge that there are many barriers to legislation that make it difficult to run a business.

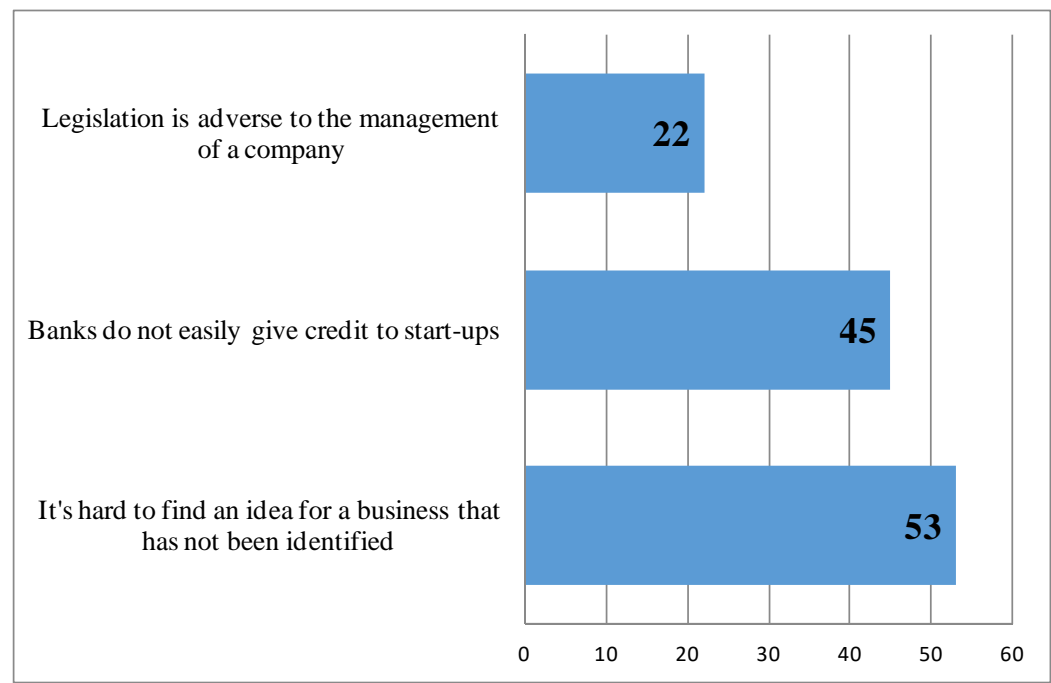

Figure 7: Perception of barriers to entrepreneurship (\% of positive responses)

In terms of risk perception, three questions were considered: (1) I like challenges. Many of life's best moments occurred as you struggled to achieve a difficult goal; (2) starting my own business is risky, I can lose everything; and (3) It is true that we are our own boss, but running our own company involves a lot of work 
INDEPENDENT JOURNAL OF MANAGEMENT \& PRODUCTION (IJM\&P)

http://www.ijmp.jor.br

v. 9, n. 4, October - December 2018

ISSN: 2236-269X

DOI: 10.14807/ijmp.v9i4.786

and responsibility and only brings great headaches. For $85 \%$ of the students, challenges are part of life; another $46 \%$ indicate that starting their own business is risky and $38 \%$ see the company as a place that causes overwork and responsibilities as well as headaches (Figure 8).

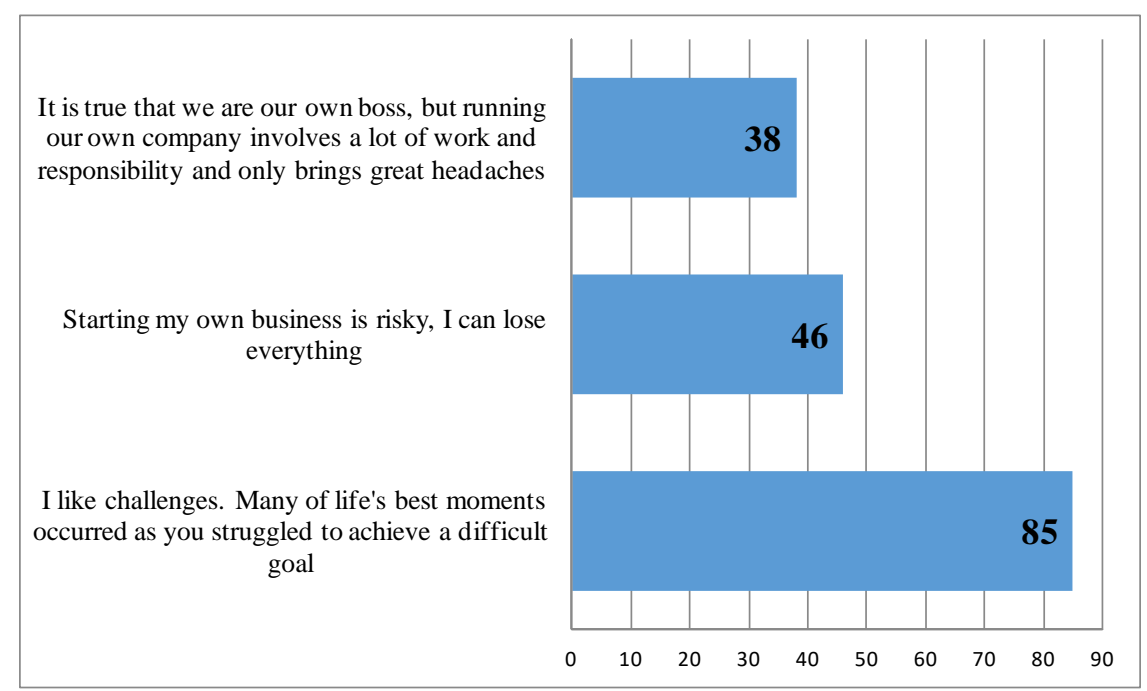

Figure 8: Perceived risk (\% of positive responses)

Consequently to perceived ability and competencies, ten questions were applied: (1) I adapt my plans to changing circumstances; (2) I am always persevering until I reach my goals; (3) I am quite confident about my technical decision-making ability; (4) I am extremely driven to achieve results; (5) If you decide to participate in setting up a business, I am confident that I will succeed; (6) my technical knowledge is very good; (7) I have a lot of self-confidence; (8) When I start something new, I know that I will be successful; (9) financial services are complicated and confusing for me; and (10) I'd rather have other people decide for me. Figure 9 shows the positive data from the survey, where $79 \%$ of students emphasize the sense of adaptation, 88\% consider themselves perseverant, 80\% confident about technical decisions, $67 \%$ focus on results, $64 \%$ do not see difficulties in the financial aspect and $93 \%$ do not like that they decide for them. 
INDEPENDENT JOURNAL OF MANAGEMENT \& PRODUCTION (IJM\&P)

http://www.ijmp.jor.br

v. 9 , n. 4, October - December 2018

ISSN: 2236-269X

DOI: 10.14807/ijmp.v9i4.786

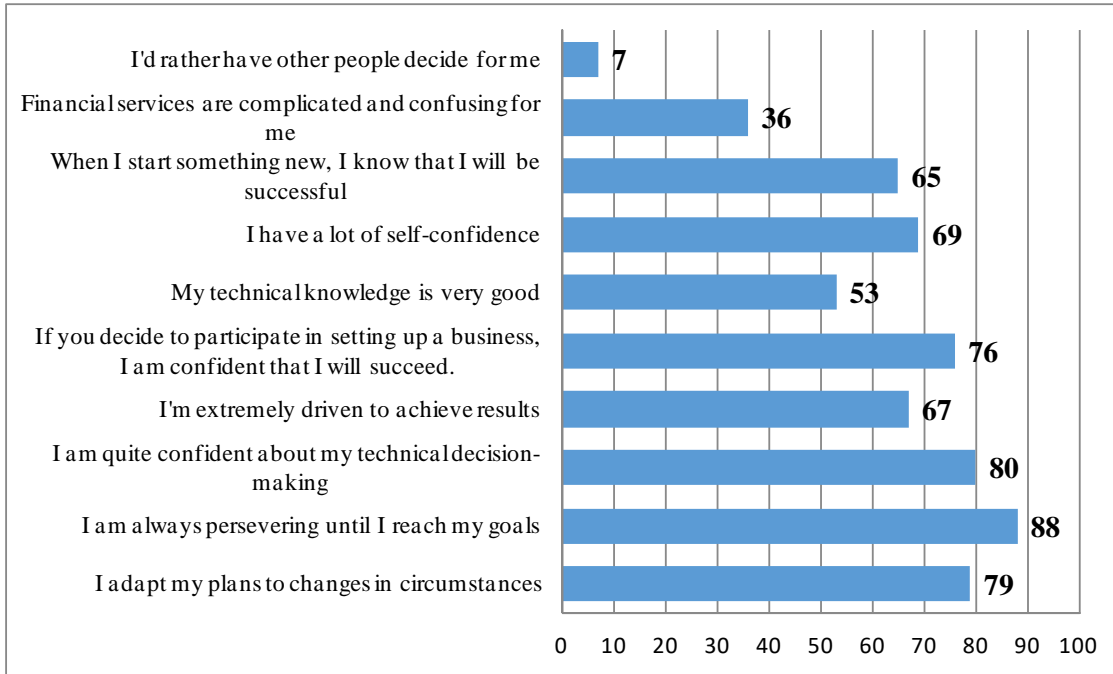

Figure 9: Perceived skills and competences (\% of positive responses)

\section{DISCUSSION}

Among the main results regarding the first part of the questionnaire dealing with the profile of the respondents, the production engineering course has a majority of female students in opposition to the national male trend. The age group shows very young students and almost $1 / 4$ of the students of the production engineering course have a family income of less than $\mathrm{R} \$ 1,000.00$.

More than half of the students do not have entrepreneurial parents and less than $1 / 4$ of the students' parents have an active business. Even with most students not having a direct link to entrepreneurship in the family, almost half of the students intend to become entrepreneurs while $1 / 4$ never thought about it and only $16 \%$ of students would give up the idea of entrepreneurship.

Because of the large percentage of students intending to become entrepreneurs, almost half of them would invest in a business of their own if they had financial resources. Traditional investments in real estate or real estate still had a considerable share of students' opinion, accounting for $37 \%$.

The study pointed out strong indications of self-employment among students at the expense of a stable career in a secure job. In this way, it is observed that from the point of view of the students, the success of the entrepreneur is not determined by the luck, but the person has a fundamental role in the entrepreneurial intention in relation to the formation. 
INDEPENDENT JOURNAL OF MANAGEMENT \& PRODUCTION (IJM\&P)

http://www.ijmp.jor.br

v. 9, n. 4, October - December 2018

ISSN: 2236-269X

DOI: 10.14807/ijmp.v9i4.786

The main barrier to entrepreneurship pointed out in the research concerns the difficulty in finding a new idea in the current context according to the majority of the students. Traditional issues involving obtaining credit and Brazilian legislation continue to be relevant impediment factors.

Positive posture was observed in dealing with risk, perhaps because it is a sample of young people, the majority of them would justify this tendency to take risks. Despite this positive aspect of risk, almost half of the students see the process of managing their own business as risky. In addition, for 3/5 of the students having their own business does not represent headaches.

With respect to perceived ability and competence, it has been shown that resilience, perseverance, confidence, focus, technical knowledge have been well evaluated by them. Even the financial question, which ends up being a major problem for most companies, has been well evaluated in the sense that it is not a hindrance to the development of companies. The competence related to the decision-making process showed the best performance, that is, for more than $90 \%$ of the students they like to make their own decisions.

Regarding the literature review, the results point to an increase in interest in this area in recent years, as pointed out by Vale et al. (2008) extrapolating the business environment. The search for a new idea pointed out by the students in the study reinforces the importance of encouraging the development of innovative entrepreneurs (VIVARELLI, 2013) or "superstars" entrepreneurs (BAUMOL, 2009) who will create new products, processes or markets, mentioned in Drucker (1986) and Saes and Pita (2007). Finally, the skills and competencies required and pointed out in the study are in line with the results verified in Hermans et al. (2007) and Teixeira et al. (2011) and evidenced in Baumol et al. (2009) as fundamental to entrepreneurial success.

The methodology adopted allowed a better understanding of the entrepreneurial intention among the students of production engineering in such a way that several aspects, such as profile of the respondents (family income, agegroup, and gender), entrepreneurial family, attitudes toward self-employment, entrepreneur, perceived risk, ability, and competencies were evaluated on both behavioral issues and future interest in the area. Likewise, the methodology is 
INDEPENDENT JOURNAL OF MANAGEMENT \& PRODUCTION (IJM\&P)

http://www.ijmp.jor.br

v. 9, n. 4, October - December 2018

ISSN: 2236-269X

DOI: 10.14807/ijmp.v9i4.786

adapted to the spectrum of scales to measure entrepreneurial intent or potential in Brazil as detailed in the literature review.

\section{CONCLUSION}

The present work had as objective to analyze the entrepreneurial intention of the students in production engineering of the Institute of Exact Sciences and Technology (ICET / UFAM) located in the municipality of Itacoatiara / AM. In view of the results found, it is believed that the objective of the research was achieved.

In terms of the main results, the first part shows the predominance of female students in the production engineering course analyzed (different from the national trend); (2) sample of the research formed by young people (predominance of students under 25 years); and (3) family income below $\mathrm{R} \$ 1,000.00$.

In the second part, the highlights were: (4) more than half of the students do not have entrepreneurial parents, (5) yet almost half of them have an intention to become entrepreneurs; (6) strong indication of self-employment; (7) seeks an innovative idea as the main barrier to entrepreneurship; and (8) resilience, perseverance, confidence, focus, and decision-making were some of the wellassessed capabilities and competencies.

As a limitation of the research, the sample considered only the students of the course of production engineering of the institute, so it is recommended for future studies the application of this instrument in other courses of the university in order to obtain a more general view of the entrepreneur's intention of the students.

In summary, the study pointed to a proactive stance regarding entrepreneurship among students of engineering production, even considering that the engineering areas concentrate a large part of their professionals as employees in public or private companies, however, the current political and economic scenario influences the professional trajectories of future engineers.

The emergence of a new technology boom (as observed in the 1990s), the rise and strengthening of the movement of incubators, technology parks and startups, the valorization of the creative economy among other correlated themes reinforce the importance of entrepreneurship as a vector important for the economic and social development of a region or country. In any case, both the image of the 
INDEPENDENT JOURNAL OF MANAGEMENT \& PRODUCTION (IJM\&P)

http://www.ijmp.jor.br

v. 9, n. 4, October - December 2018

ISSN: 2236-269X

DOI: 10.14807/ijmp.v9i4.786

entrepreneur and the idea of becoming one are very well seen by the students of production engineering of the studied institution.

The relevance of the research lies in evidencing the growth of entrepreneurship among students of production engineering so that the university contributes to the formation of professionals who will create high added-value enterprises, promoting technological development and innovation and impacting local development.

\section{REFERENCES}

ÁCS, Z. J.; et al. (2017) GEDI - Global Entrepreneurship Index 2017. USA.

ÁCS, Z. J.; AUTIO, E.; SZERB, L. (2014) National Systems of entrepreneurship: measurement issues and policy implications. Research Policy, v. 43, n. 3, p. 476494.

ALVES, A. R. (2011) Empreendedorismo. Editora E-Tec Brasil.

ALVES, L. R. R.; BORNIA, A. C. (2011) Desenvolvimento de uma escala para medir o potencial empreendedor utilizando a Teoria da Resposta ao Item (TRI). Gestão \& Produção, v. 18, n. 4, p. 775-790.

BAUMOL, W. J.; SCHILLING, M.; WOLFF, E. N. (2009) The superstars inventors and entrepreneurs: how were they educated? Journal of Economic and Management Strategy, v. 18, n. 3, p. 711-728.

CASSAR, G. (2007) Money, money, money? a longitudinal investigation of entrepreneurship career reasons, growth preferences and achieved growth. Entrepreneurship and regional development, v. 19, n. 1, p. 822-840.

DORNELAS, J. C. A. (2004) Empreendedorismo corporativo: Conceitos e aplicações. Revista de negócios, v. 9, n. 2, p. 81-90.

DRUCKER, P. (1986) Inovação e espírito empreendedor: prática e princípios. São Paulo: Pioneira Thomson Learning.

GIL, A. C. (2002) Como elaborar projetos de pesquisa. 4. ed. São Paulo: Atlas.

HERMANS, J.; et al. (2015) Ambitious entrepreneurship: a review of aspirations, intentions, expectations, and growth. In: A.C. Corbett, J. Katz, and A. McKelvie eds, Firm emergence and growth: advances in entrepreneurship. v. 17. Bingley: Emerald.

INÁCIO JÚNIOR, E..; GIMENEZ, F. A. P. (2004) Potencial empreendedor: um instrumento para mensuração. Revista de Negócios, v. 9, n. 2, p. 107-116.

KRUEGER JR, N. F.; REILLY, M. D.; CARSRUD, A. L. (2000) Competing models of entrepreneurial intentions. Journal of Business Venturing, v. 15, p. 411-432.

LEE, L.; WONG, P. K.; FOO, M. D.; LEUNG, A. (2011) Entrepreneurial intentions: the influence of organizational and individual factors. Journal of Business Venturing, v. 26, p. 124-136. 
INDEPENDENT JOURNAL OF MANAGEMENT \& PRODUCTION (IJM\&P)

http://www.ijmp.jor.br

v. 9, n. 4, October - December 2018

ISSN: 2236-269X

DOI: 10.14807/ijmp.v9i4.786

LOPES JUNIOR, G. S.; SOUSA, E. C. L. (2005) Atitude empreendedora em proprietários-gerentes de pequenas empresas: construção de um instrumento de medida. REAd. Revista Eletrônica de Administração, v. 11, n. 6, p. 1-21.

MARCONI, M. A.; LAKATOS, E. M. (1990) Técnicas de pesquisa: planejamento e execução de pesquisas, amostragens e técnicas de pesquisa, elaboração, análise e interpretação de dados. 2a ed. São Paulo: Atlas.

MALHEIROS, R.; FERLA, L. A.; CUNHA, C.J.C.A. (2005) Viagem ao mundo do Empreendedorismo. IEA: Florianópolis, IEA - Instituto de Estudos Avançados.

RIFKIN, J. (2014) The zero marginal cost society. New York: Palgrave Macmillan.

SAES, D. X.; PITA, F. H. S. (2007) Empreendedorismo no ensino superior: uma abordagem teórica. Revista de Ciências Empresariais, v. 4, n. 2, p. 33-41.

SANTOS, P. C. F. (2008) Uma escala para identificar potencial empreendedor. 2008. 364 f. Tese (Doutorado em Engenharia de Produção)-Universidade Federal de Santa Catarina, Florianópolis.

SCHUMPETER, J. A. (1961) Capitalismo, socialismo e democracia. Rio de Janeiro: Fundo de cultura.

SCHUMPETER, J. A. (1997) Teoria do desenvolvimento econômico. São Paulo: Nova Cultural.

SCHWAB, K. (2015, December 12). The fourth industrial revolution: what it means and how to respond. Retrieved january 10, 2016, from https://www.foreignaffairs.com/articles/2015-12-12/fourth-industrial-revolution.

SILVA, E. L.; MENEZES, E. M. (2005) Metodologia da pesquisa e elaboração de dissertação. 4. ed. Florianópolis: UFSC.

SILVA, F. A. (2014) Geração de valor. Rio de Janeiro: GMT Editores.

SILVA, T.; et. al. (2013) Considerações sobre inovação e atividade empreendedora na trajetória sul coreana. RAI - Revista de Administração e Inovação, v. 10, n.4, p. 283-307.

TEIXEIRA, R. M.; et al. (2011) Empreendedorismo jovem e a influência da família: a história de vida de uma empreendedora de sucesso. REGE - Revista de Gestão, v. 18, n. 1, p. 3-18.

VIEIRA, F. D.; RODRIGUES, C. S. (2014) Os estudantes de engenharia e as suas intenções empreendedoras. Revista Produção Online, v.14, n. 1, p. 242-263.

VALE, V. G.; WILKINSON, J.; AMÂNCIO, R. (2008) Empreendedorismo, inovação e redes: uma nova abordagem eletrônica. RAE-eletrônica, v. 7 n. 1, Art. 7. 